\title{
Research Paper \\ The effect of Mindfulness Training on Emotional Self-Regulation and Psychological Resilience of Unsupervised Children
}

\author{
Ali Akbar Nahang*1, Fahimeh Mosavi Najafi ${ }^{2}$, Roya Mohammadi ${ }^{3}$ \\ 1. M.A. in Clinical Psychology, Tehran (Saveh) Research Branch, Islamic Azad University, Tehran, Iran \\ 2. M.A. in General Psychology, Isfahan (Khorasgan) Branch, Islamic Azad University, Isfahan, Iran \\ 3. M.A. in General Psychology, Tehran (Fars) Research Branch, Islamic Azad University, Tehran, Iran
}

Citation: Nahang AA, Mosavi Najafi F, Mohammadi R. The effect of mindfulness training on emotional self-regulation and psychological resilience of unsupervised children. Quarterly Journal of Child Mental Health. 2020; 7(1): 106-117.

http://dx.doi.org/10.29252/jcmh.7.1.10

\section{A R T I C L E I N F O}

\author{
Keywords: \\ Emotional self- \\ regulation, \\ resilience, \\ mindfulness, \\ unsupervised children
}

Received: 20 Apr 2018

Accepted: 20 Nov 2018

Available: 15 Jun 2020

\section{A B S T R A C T}

Background and Purpose: Unsupervised children are more at risk for maladaptive behaviors than other peers, and therefore need more psychological therapy compared to their peers. Therefore the objective of the present study was to investigate the effectiveness of child-based mindfulness on emotional self-regulation and psychological resilience of unsupervised children.

Method: The method of the present study was semi-experimental with pre-test-post-test design with a control group. The statistical population of this study included all primary unsupervised children aged 9 to 13 in Tehran city in the academic year of 2017-2018. The sample consisted of 40 children from the statistical population who were selected by convenient sampling method and randomly assigned to two experimental and control groups. Then the child-centered mindfulness intervention was presented to the experimental group in ten 60-minute sessions over three months, and the control group did not receive the intervention. The applied questionnaires included Emotional SelfRegulation Questionnaire (Garous and John, 2003) and Children and Adolescents Resilience Scale (Engar and Libenberg, 2009). Data analysis was performed by covariance analysis and $\mathrm{SPSS}_{23}$ software

Results: The results of data analysis showed that the effect of mindfulness on emotional selfregulation $(\mathrm{P}<0.001 ; \mathrm{F}=94.56)$ and psychological resilience $(\mathrm{P}<0.001 ; \mathrm{F}=74.22)$ in unsupervised children, was positive.

Conclusion: Based on the findings of the present study, it can be concluded that the child-based mindfulness has caused feelings without judgment and beyond consciousness in children, and as a result, has led to positive changes in the sample.

\footnotetext{
* Corresponding author: Ali Akbar Nahang, M.A. in Clinical Psychology, Tehran (Saveh) Research Branch, Islamic Azad University, Tehran, Iran.

E-mail addresses: Nahangaliakbar@gmail.com
} 


\section{تأثير آموزش ذهن آكاهى بر خودنظمبخشى هيجانى و تابآورى روانشناختى كود كان بدسريرست}

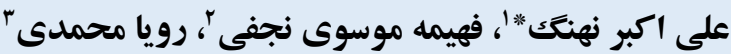

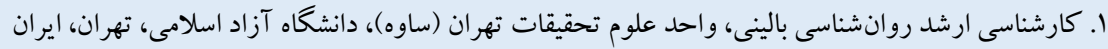

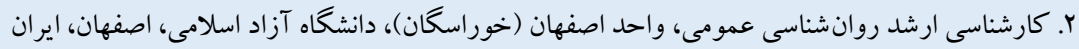

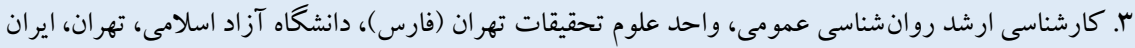

?

زمينه و هدف: كودكان بدسريرست بيش از ساير همسالان در معرض خطر رفتارهاى غيرانطباقى قرار دارند كه در نتيجه به كارگيرى

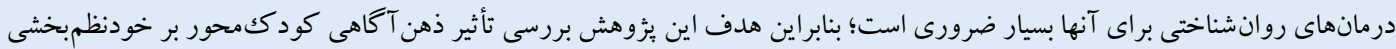

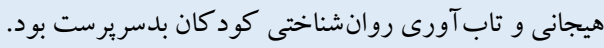

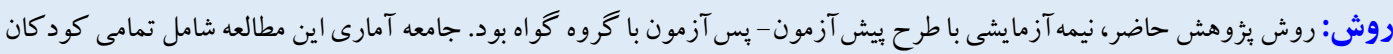

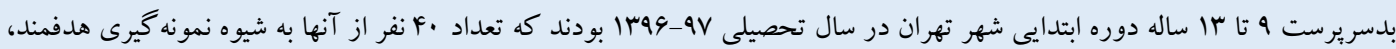

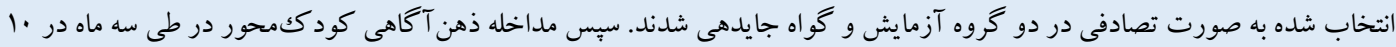

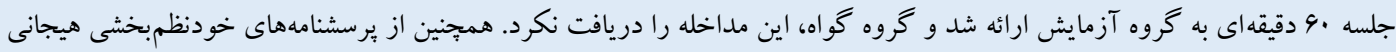

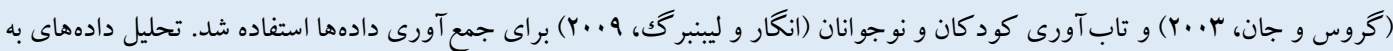
دست آمده با شيوه تحليل كواريانس و با نرمافزار آمارى

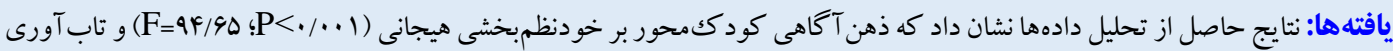

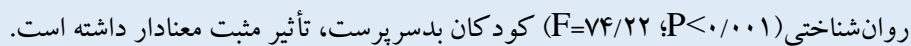
نتيجه كيرى: بر اساس يافتهاى بُوهش حاضر مى توان جنين نتيجه گرفت كه ذهن آكاهى كودككمحور باعث احساس بدون قضاوت و فراتر از آكاهى در كود كان شده است و در نتيجه تغييرات مثبى را در افراد نمونه، منجر شده است.
مشخصات مقاله

كليدوازهها:

خو دنظمبخشى هيجانى، تاب آورى، ذهن آكَاهى، كود كان بدسريرست

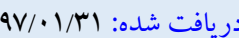

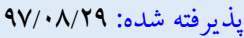

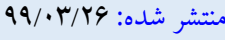

* نويسنده مسئول: على اكبر نهنگ، كارشناسى ارشد روانشناسى بالينى، واحد علوم تحقيقات تهر ان (ساوه)، دانشگاه آزاد اسلامى، تهران، ايران. رايانامه: Nahangaliakbar@gmail.com

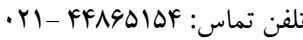


نتيجه آنان فر صت كفتمان هيجانى كمترى را تجربه مى كنند. نار سايى در

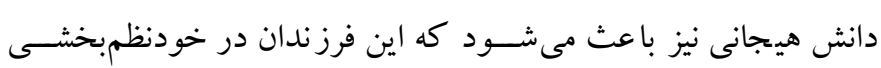

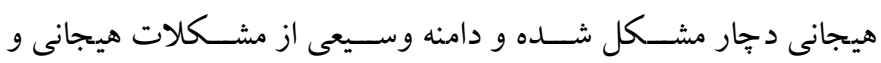

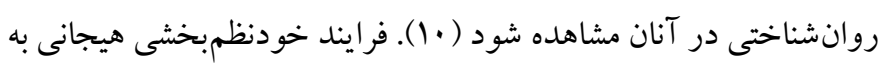

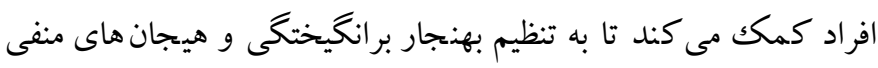

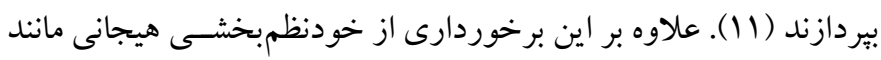
ارزيابى مجدد باعث كاهش احساسات منفى و افزايش احساسات مثبت و

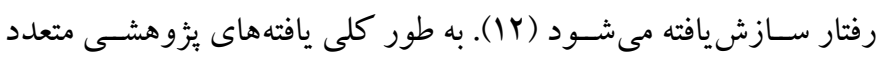

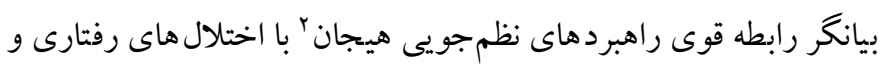

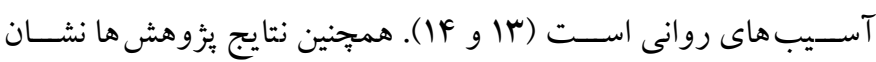

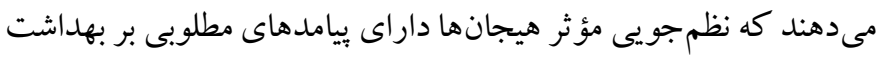

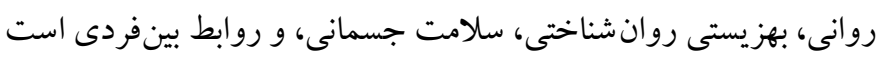

يكى از مؤلفه هاى روانشناختى كه مى تواند به تحول بهنجار كود كان

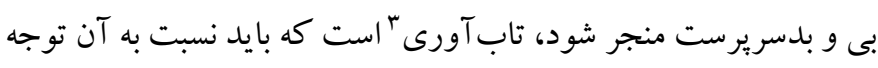

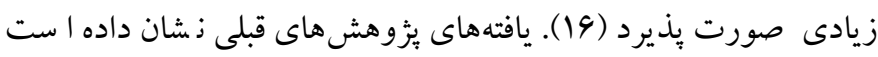

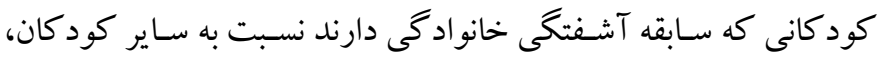

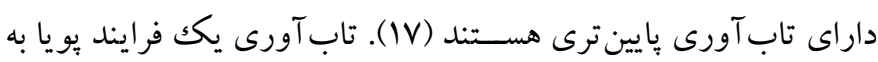

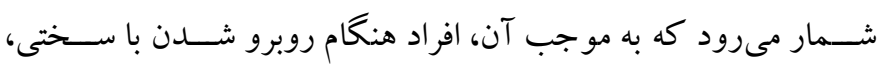

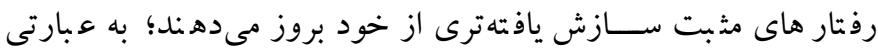
تاب آورى به مفهوم تو انايى يا قدرت باز گثــت به حالت يا موقعيت اوليه

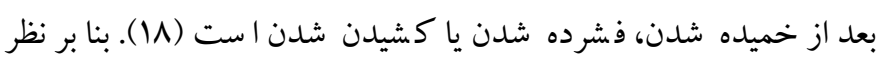

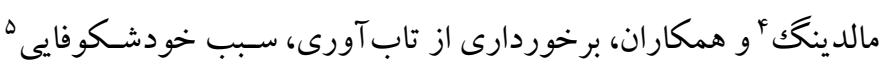

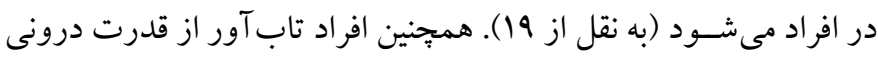

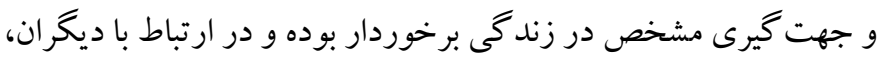

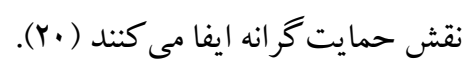

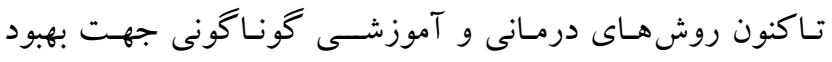

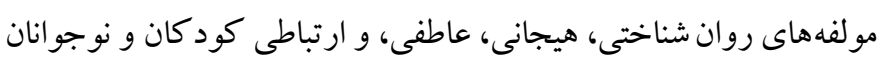

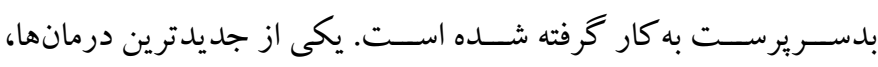

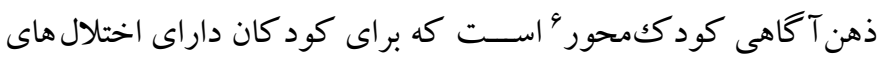

\section{Mulding}

5 .Self- actualization

6. Mindfulness Child- Based Therapy
مقلهم

كود كان نخستين بار زندگى را در كانون خانو اده تجربه مى كنند و هـته

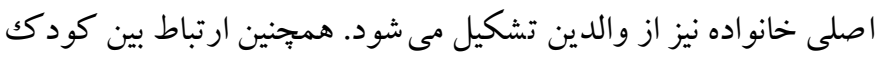

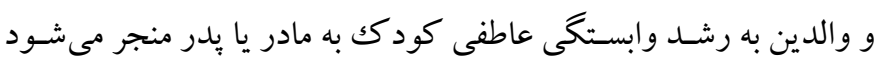

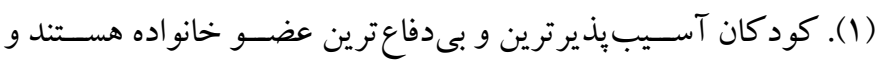

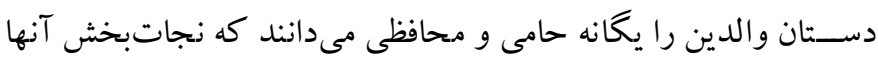

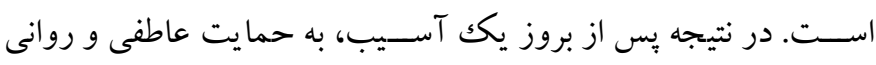

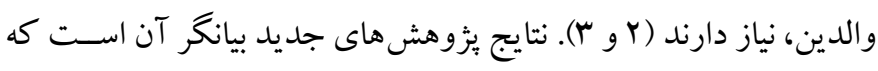

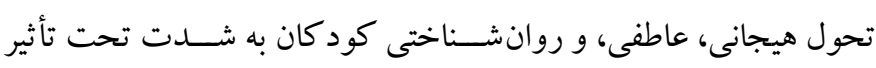

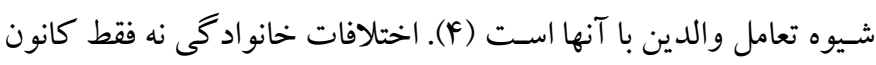
خانو اده را درهم مى ريزد و سـلامت جسـمى و و روانى كود كان را مختل

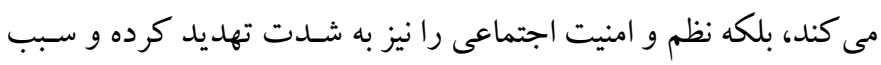

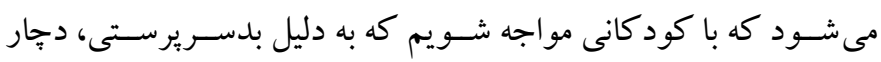

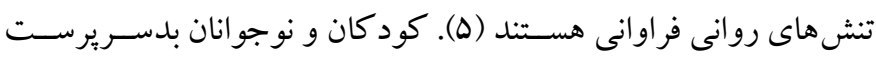

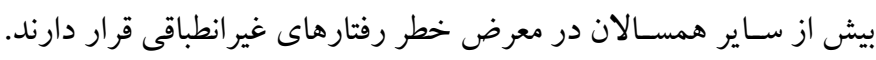

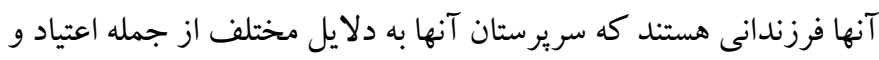

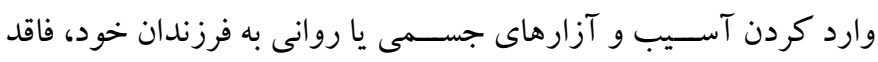

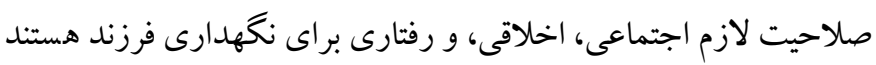

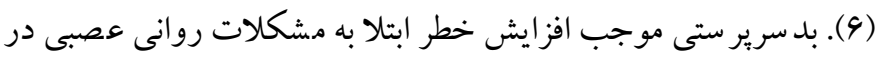

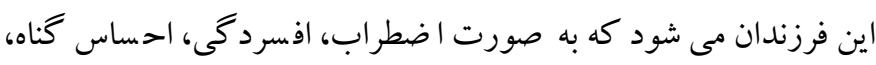
ناميدى، ترس، خشم شده و در نهايت به كاهش شادزيستى در آنها منجر

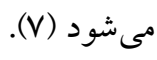
تحول كود كان بدون والدين يا والدين فاقد صـلاحيت اخلاقى و

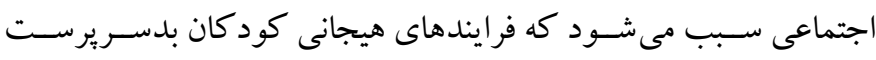

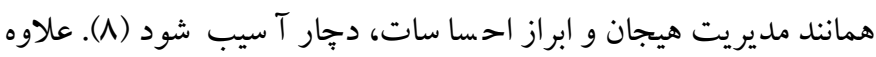

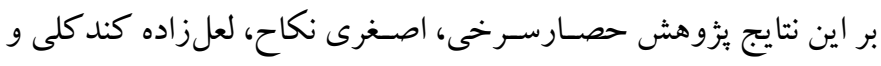

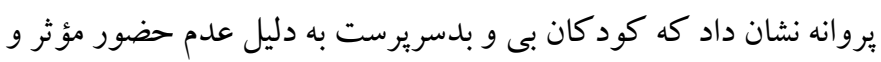
مفيد والدين و يا خشــــت و تنبيه هاى آنان، در فرايندهاى هيجانى نظير

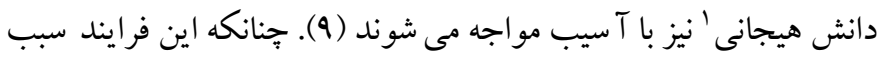

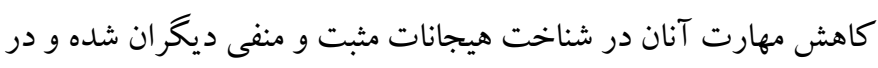

1. Emotional knowledge

2. Emotion regulation strategies

3. Resiliency 
بودن مطالعات انجام شده از سويى ديخر، مسئله اصلى ئزوهش حاضر اين

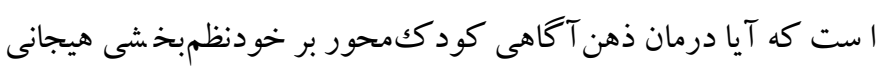
و تاب آورى كود كان بدسريرست تأثير دارد؟

الف) طرح هزوهش و شــر كت كن ند كان: روش ئزوهش از نوع

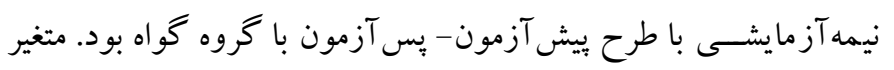

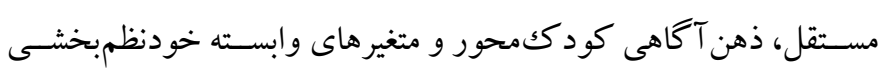

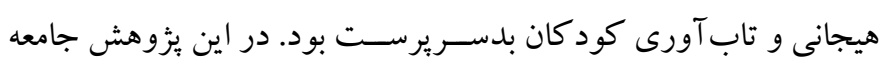

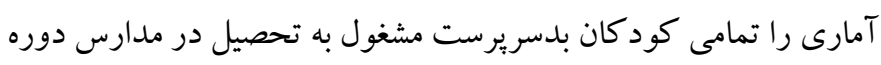

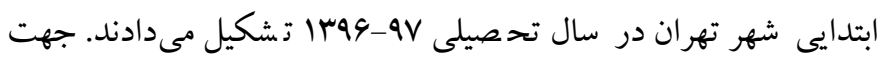
انتخاب حجم نمونه از روش نمونه گيرى غير تصادفى هدفمند استفاده شد.

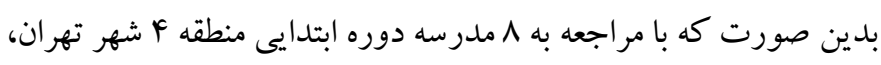

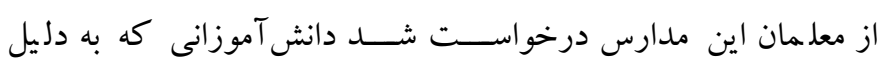

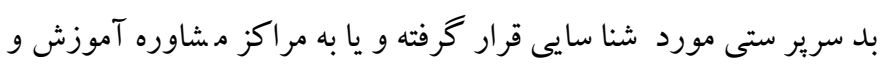

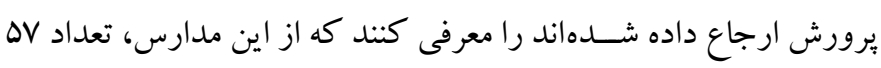

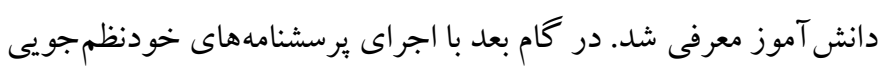

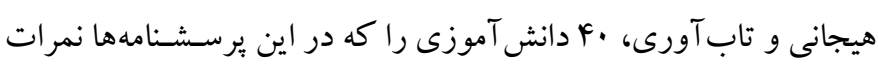

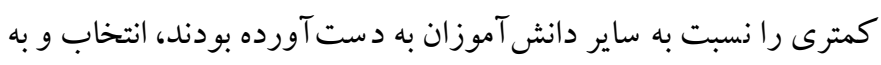

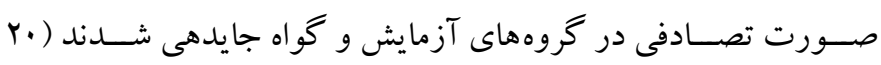

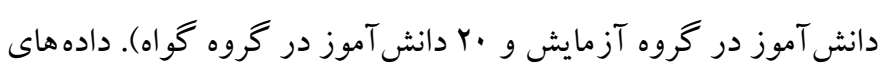

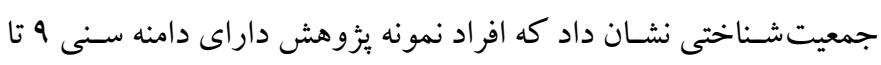

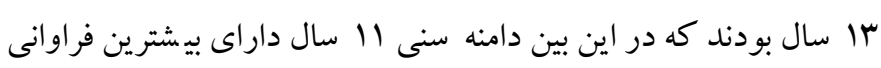
بود ( اله درصـد). از طرفى اين افراد در دوره ابتدايى مشـغول به تحصسيل

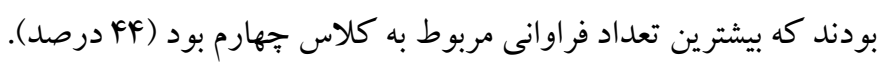

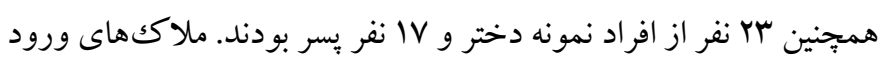

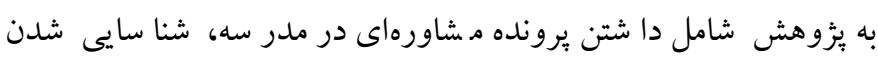

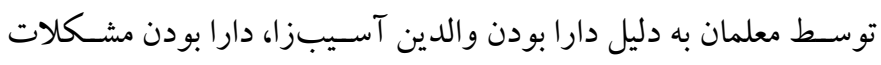

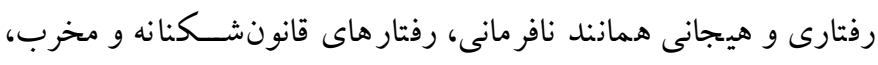

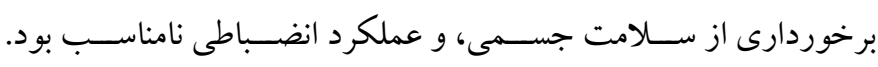

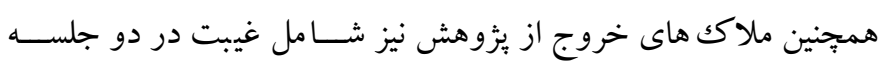

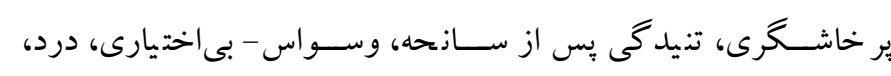
افسردگى و نظاير آن به كار رفته است (IY) (Y). علاوه بر اين كار آيى بالينى

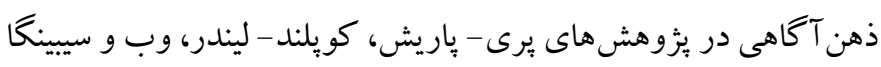

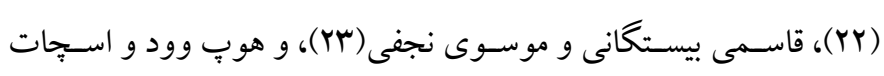

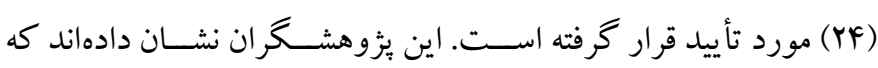

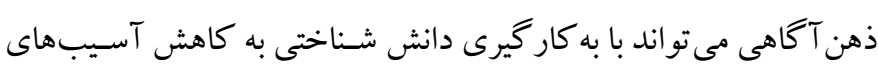

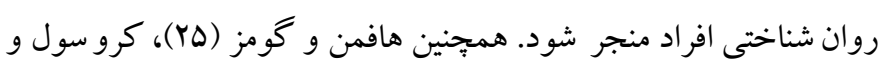

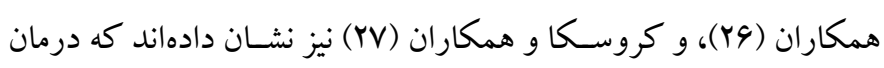

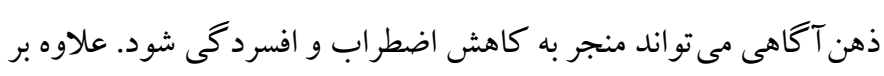

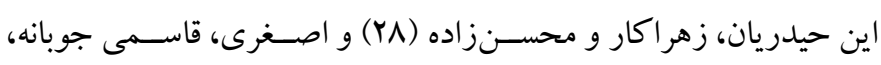

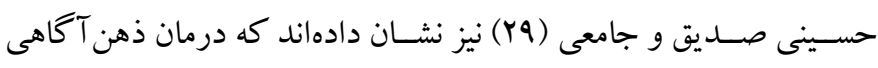

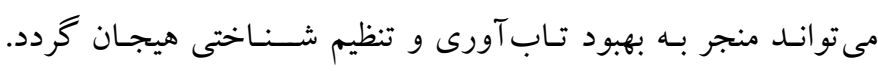

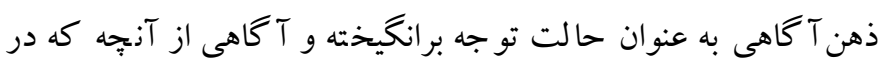

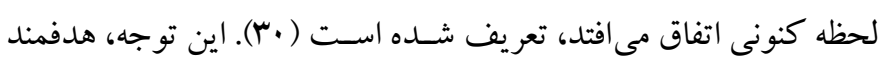

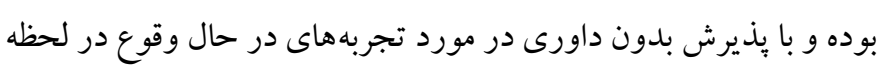

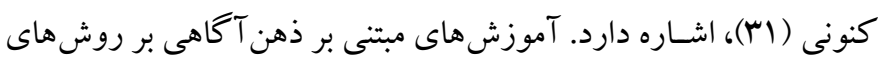

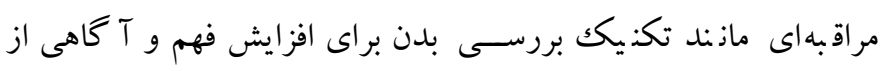

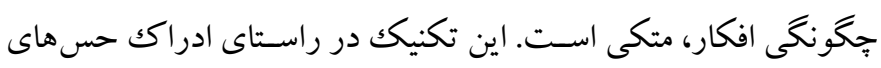

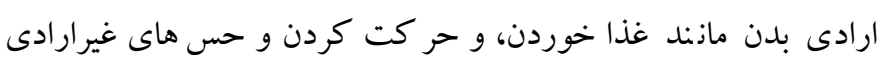

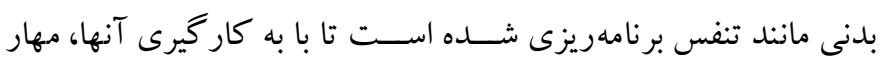

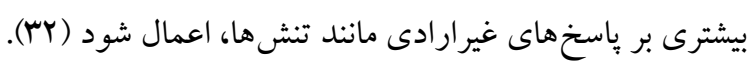

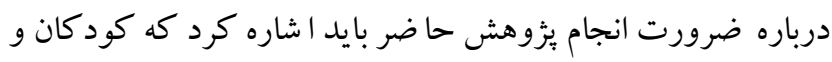

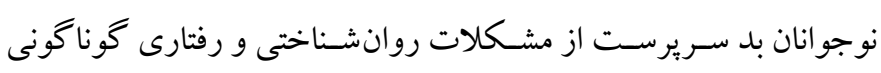
رنج مىبرند و از حمايت مناسب، محافظت و تأييد بزر خسالان و همسالان ونسان

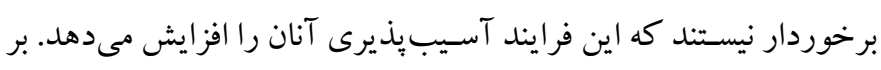

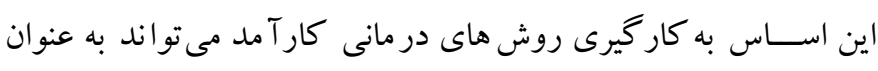
راهگشايى در جهت بهبود مؤلفهاى روان شناختى اين كود كان به شمار رود. حال با تو جه به آسـيب هاى روانش-ناختى و هيججانى كود كان

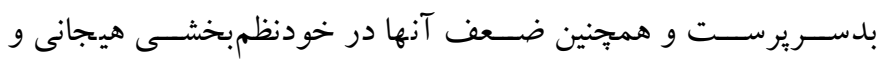

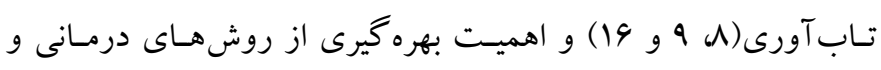

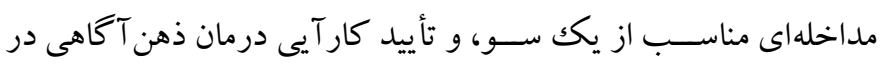

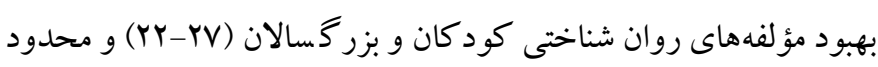


كه براى كود كان و نوجو انان قابل اجرا اسـت. اين برسـشــنامه داراى بـ

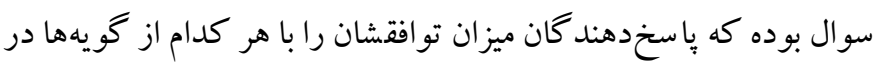

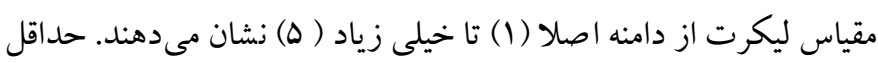

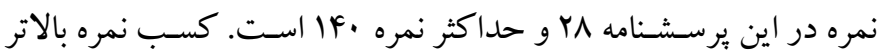

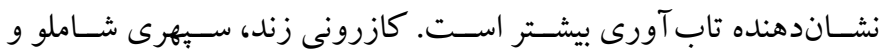
ميرزائيان جهت بررسـى روايى همز مان مقياس تابَآورى كود كان و

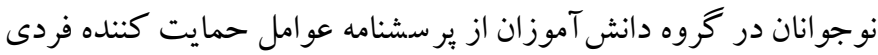

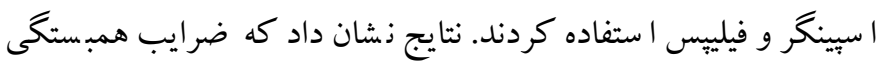

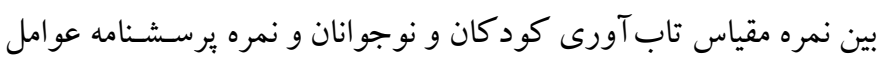
حمايت كننده فردى و زيرمقياسهايش، مثبت و معنى دار اسـت. همجِنين

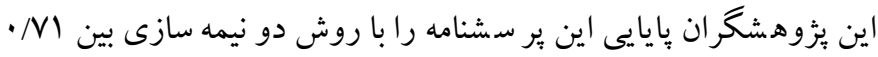

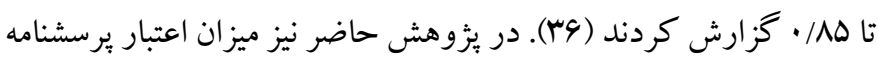

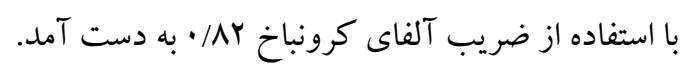

ج) برنامه مداخلهاى: برنامه مداخلهاى به كار گر فته شده در اين مطالعه

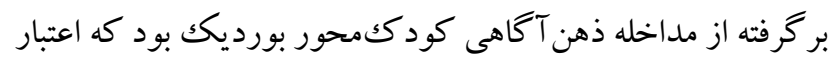

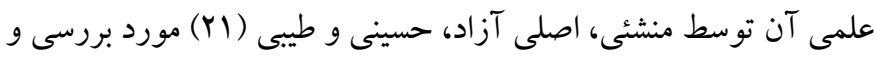

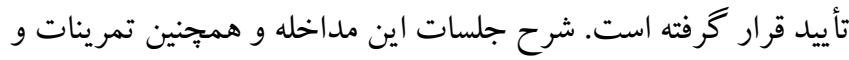
استعارههاى به كار رفته در آن، مختص سن كودكى است. اين جلسات

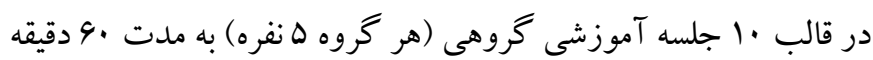

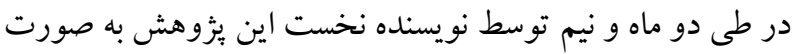

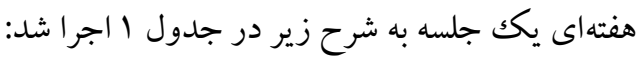

آموزشى و عدم همكارى لازم و انجام ندادن تكاليف مشـخص شـده در دوره آموزشى بود.

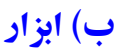

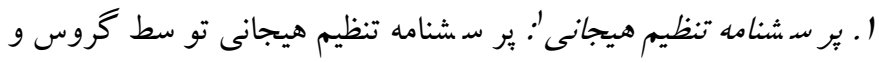

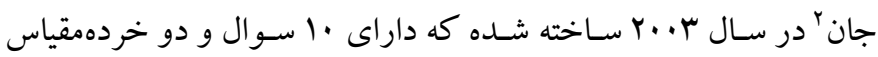
بازدارى هيجانى و ارزيابى مجدد شناختى است. آزمودنى به هر كويه اين

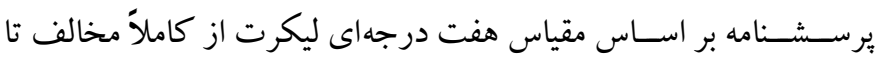

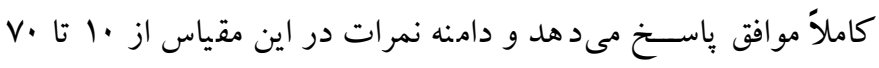

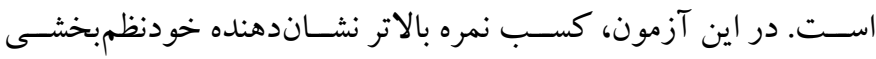

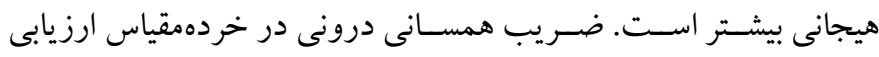

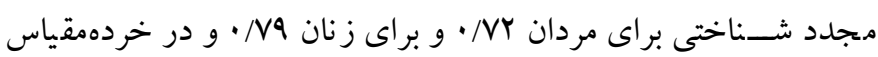

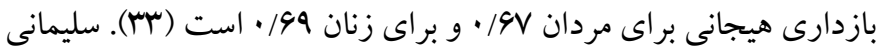

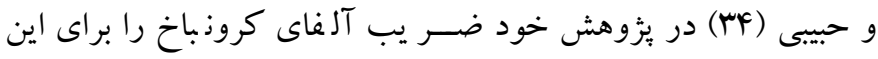

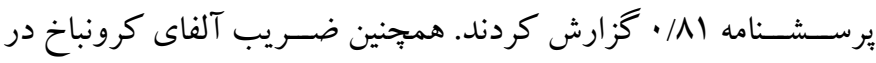

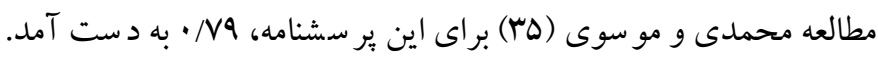

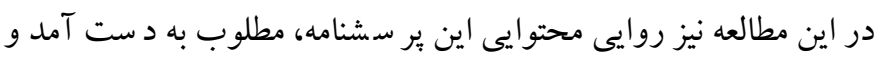

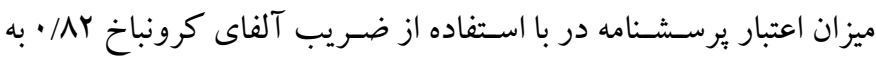

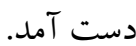
r. برسشنامه تاب آورى كودكان و نوجوانان"ّ. مقياس تاب آورى كود كان

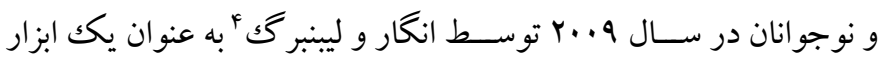
تفكيكك براى كشف منابع فردى، ارتباطى، و بافتى تاب آورى طراحى شد دئر

\section{جدول ا: خلاصه جلسات ذهن آكاهى كود كمحور}

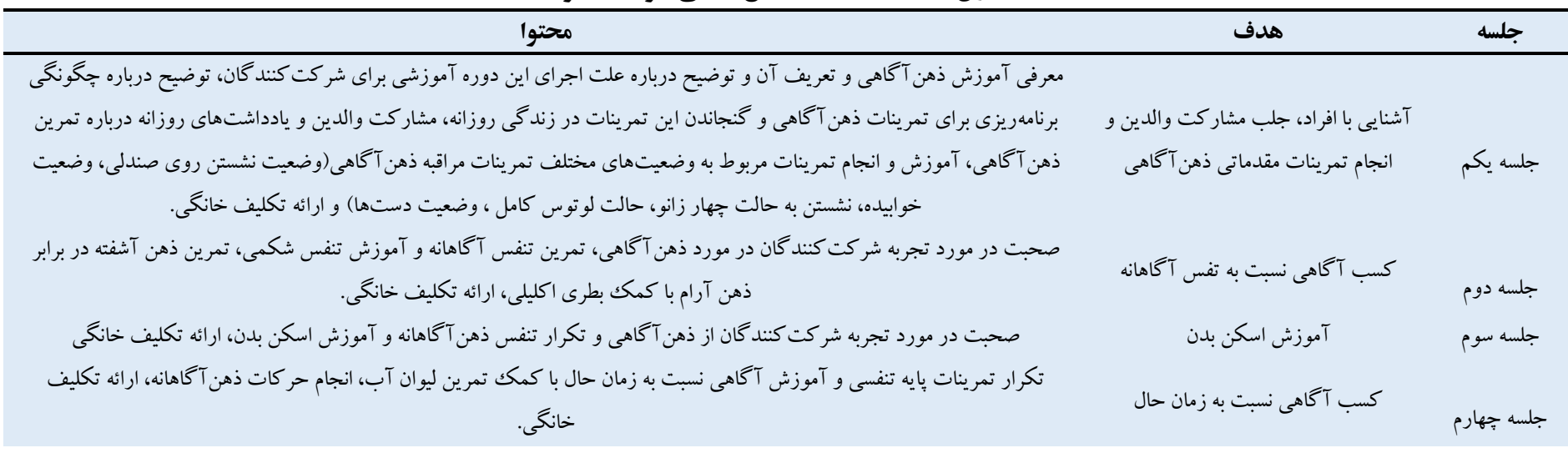

3. Children and adolescents resilience questionnaire 4. Ungar, Liebenberg
1. Emotional regulation questionnaire

2. Gross, John 


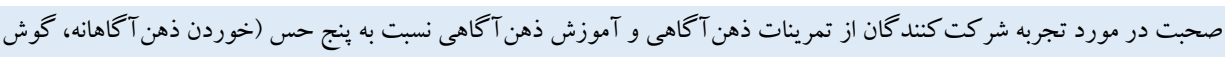

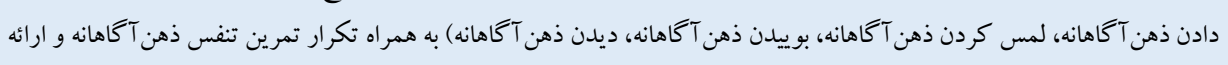

$$
\text { تكليف خانكى. }
$$

كسب آكاهى نسبت به اعمال بنج حس

اصلى بدن

جلسه ينجم

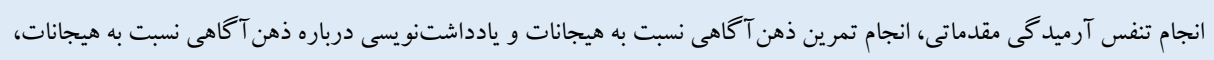

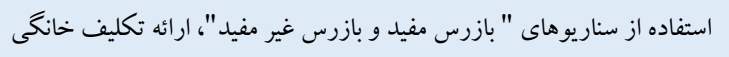

كسب آكاهى نسبت به هيجانات

جلسه ششم

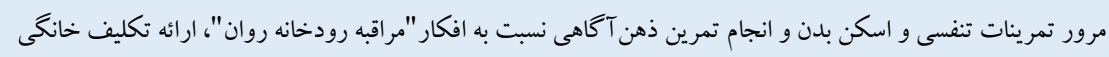

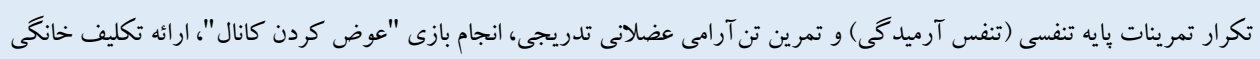

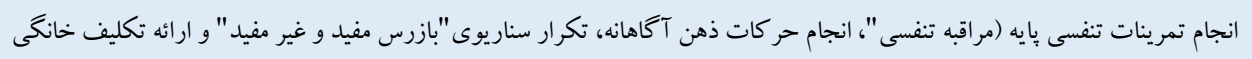

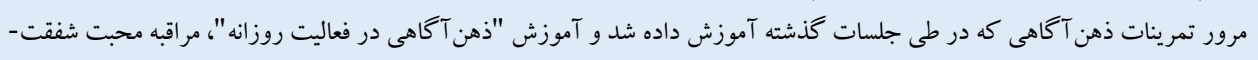

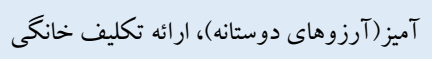

$$
\text { مرور تمرينات تنفسى }
$$

كسب آكاهي نسبت به عملكر د عضلات

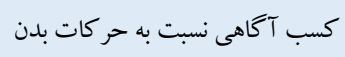

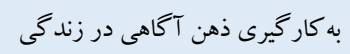

جلسه هنتم

جلسه هشتم

جلسه نهم

جلسه دهم
در اين يثروهش براى تجزيه و تحليل دادهها از دو سطح آمار توصيفى

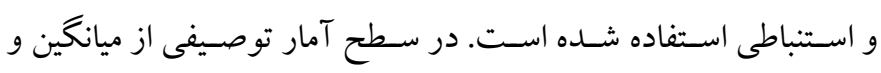

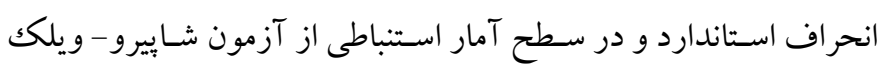

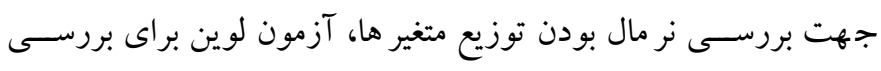

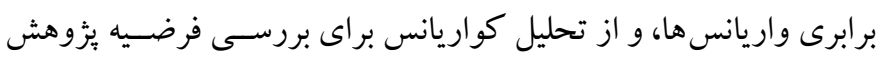

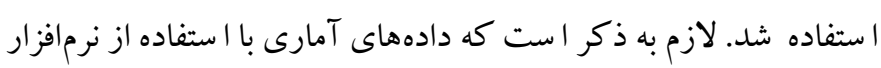
آمارى سץ-SPSS تجزيه و تحليل شده است.

\section{يافته ها}

يافته هاى توصسيفى اين بثزوهش شـامل ميانخين و انحراف معيار متغير هاى خودنظمبخشى هيجانى و تاب آورى كود كان بد سربر ست در خروههاى

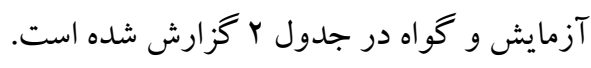

د) روش اجرا: جهت انجام اين بزوهش ابتدا هماهنگى هاى لازم با

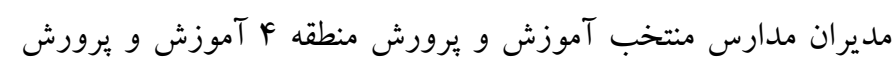

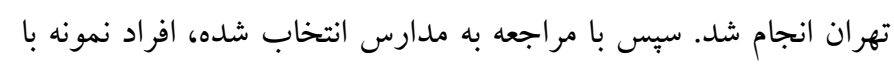
رضايت كتبى انتخاب شده و به صورت تصادفى در گروههاى آزمايش و

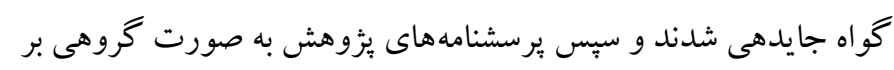

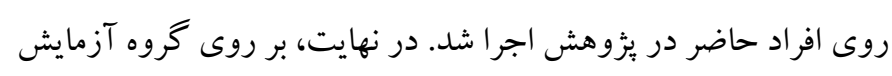

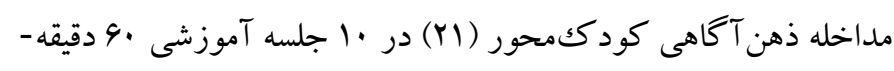

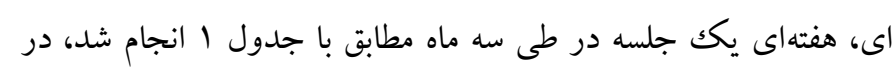

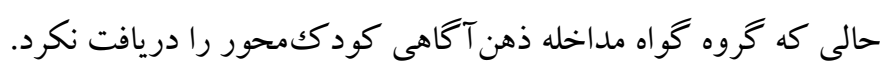

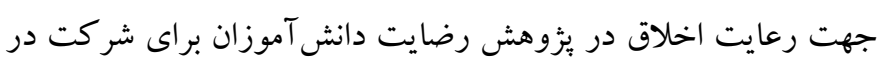

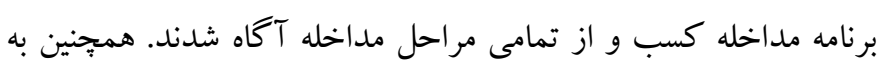

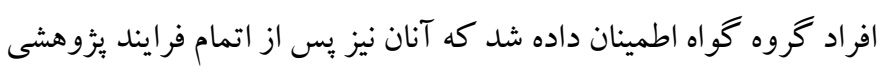

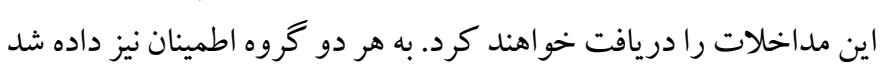
كه اطلاعات آنها محرمانه باقى مى ماند و نيازى به درج نام نيست.

\begin{tabular}{|c|c|c|c|c|c|c|c|c|}
\hline \multirow{2}{*}{ نرماليتى دادهها } & \multicolumn{2}{|c|}{ يس آزمون } & \multirow{2}{*}{ نرماليتى دادهها } & \multicolumn{2}{|c|}{ يُشيش آزمون } & \multirow{2}{*}{ كرووها } & \multirow{2}{*}{\multicolumn{2}{|c|}{ مؤلفه ها }} \\
\hline & انحراف معيار & ميانكين & & انحر اف معيار & ميانكين & & & \\
\hline.$/ \mathrm{V}$ & 9190 & Fr/AD & 每/ & $\Delta / \Delta Q$ & $r Y / l$. & گروه آزمايش & \multirow{2}{*}{\multicolumn{2}{|c|}{ نمره كل خو دنظمبخشى هيجانى }} \\
\hline$\cdot|r|$ & $\Delta / Q Y$ & rF &.$/ I V$ & $9 / 11$ & $\mu F / r \Delta$ & كروه كو اه & & \\
\hline$\cdot / \mathrm{IV}$ & $r / 90$ & 19 &.$/ 19$ & $r / 9 r$ & $11 / V \Delta$ & كروه آزمايش & \multirow{2}{*}{ بازدارى هيجانى } & \\
\hline$\cdot / \mathrm{V}$ & $r / \Delta \Delta$ & $\mid r / T \Delta$ & $\cdot / r 1$ & $r / \Delta$. & $\mid r / r$ & كروه گواه & & \\
\hline$\cdot / Y F$ & $F / Y F$ & TV/AD & r/ & $F / I V$ & $r \cdot / r \Delta$ & كروه آزمايش & \multirow{2}{*}{ ارزيابى مجدد شناختى } & \multirow[b]{2}{*}{ ى هيجانى } \\
\hline .119 & $p / r q$ & YI/VD &.$/$ If & $F / Y \Lambda$ & $r Y / / D$ & كروه گواه & & \\
\hline$\cdot / r q$ & $9 / 94$ & $a r / 4$. & $\cdot / A V$ & G/VA & $V Q / 9$. & كروه آزمايش & & \\
\hline.$/ \mathrm{F}$ & 9/99 & $V \pi / r \Delta$ & $\cdot / Y_{F}$ & G/VA & $v i / r$. & گروه گواه & & تابآورى \\
\hline
\end{tabular}

جدول r: ميانتين و انحر اف معيار خودنظمبخشى هيجانى و تابَآورى كود كان بدسريرست بر اساس كروه آزمايش و كواه 
است كه فرض همكنى شيب خط ركر سيون در اين متغيرها برقرار بوده اســت. نتايج آزمون باكس براى بررســى برابرى ماتريس كوار يانس متغيرهاى وابسته (جهت بررسـى خردهمقياس هاى متغير خودنظمبخشى هيجانى: ابراز خرى هيجانى و بازدارى شــناختى هيجان) در بين دو گروه آزمايش و كواه نيز ذشان داد كه ماتريس كواريانس متغيرهاى وابـسته در

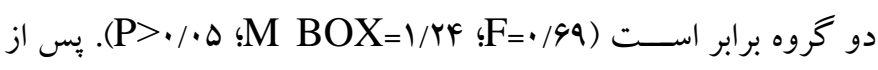
بررسـى بيش فرض ها، نتايج يزٔوهش در دو قسـمت ارائه مىشـود. ابتدا نتايج مربوط به نمره كل تاب آورى و خودنظمبخشىى هيجانى در قالب تحليل كواريانس تككمتغيرى يكراهه ارائه مى شــود (به دليل نداشــتن خردهمقياس در يرسـشــنامه تابـآورى) و ســـس نتايج مربوط به تحليل كوار يانس جِندمتغيرى يكرا هه جهت بروسـى خردهمقياس هاى متغير خودنظمبخشى هيجانى ارائه مىشود. در جدول ب نتايج تحليل كواريانس تأثير عضسويت كروهى بر خودنظمبخشى هيجانى و تاب آورى كود كان

$$
\text { بدسريرست ارائه شده است. }
$$

قبل از ارائه نتـايج تحليل آزمون كواريـانس، بيش فرضهـاى

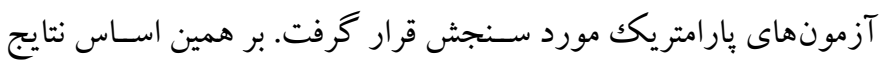

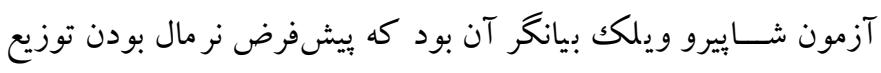

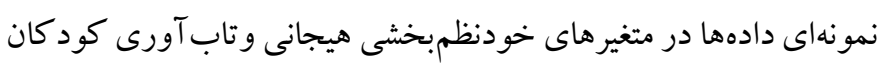

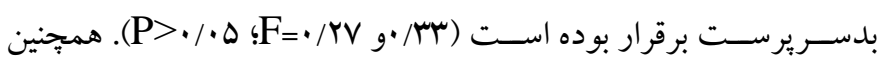

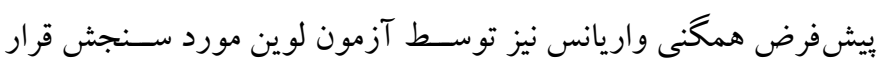

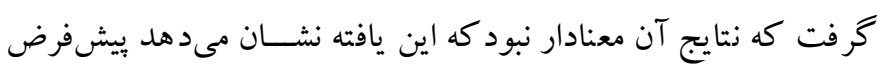

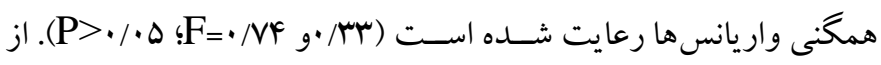

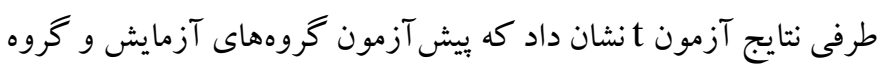

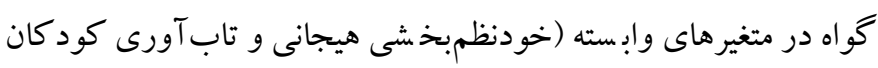

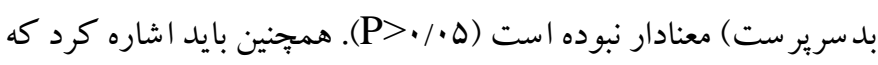

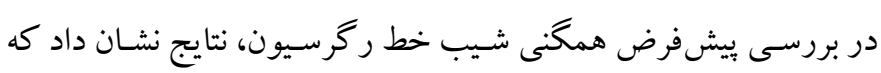

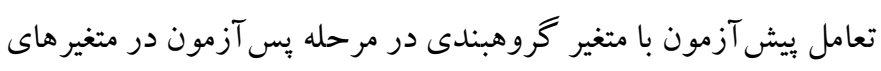

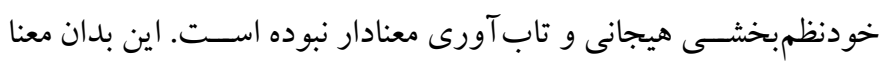

جدول rا: تحليل كواريانس تأثير عضويت كروهى بر خودنظمبخشى هيجانى و تابآورى كود كان بدسريرست

\begin{tabular}{|c|c|c|c|c|c|c|c|c|}
\hline توان & اندازه اثر & معنادارى سطح & $\mathbf{F}$ & مجذورات مجين & درجه آزادى & مجموع مجذورات & شاخصهاى آمارى & متغيرها \\
\hline.$/ 99$ & $\cdot / 01$ & $\cdot / \cdots 1$ & $\Delta \cdot / \Delta r$ & $W F / F V$ & 1 & $V W F / F V$ & ي يش آزمون & \multirow{3}{*}{ خو دنظمبخشى هيجانى } \\
\hline \multirow[t]{2}{*}{1} & $\cdot / N r$ & $\cdot / \cdots 1$ & $94 / 90$ & $\mid r V F / I T$ & 1 & IrVF/IT & عضويت گروهى & \\
\hline & & & & $1 r / 49$ & rv & $F q \Lambda / \cdot V$ & خطا & \\
\hline$\cdot / \cdot V$ & $\% \Delta$ & .194 &.$/ 19$ & Q/४^ & 1 & Q/४^ & ي ي يش آزمون & \multirow{3}{*}{ تاب آورى } \\
\hline \multirow[t]{2}{*}{1} & .199 & $\cdot / \cdots, 1$ & $V F / r r$ & TOYY/rD & 1 & rorr/ro & عضويت گروهى & \\
\hline & & & & $F V / F G$ & rv & IVDQ/৭Q & خطا & \\
\hline
\end{tabular}

و 194 • بوده اســت، اين بدان معناســت كه به ترتيب VY و 49 درصـــ تغييرات متغيرهـاى خودنظمبخشـى هيجـانى و تـابـآورى كودكـان بدسريرست توسط عضويت گروهى (مداخله ذهن آ گاهى كود ككمحور)

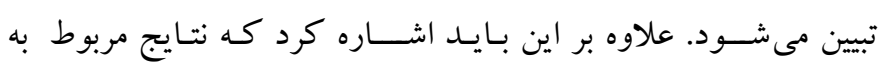

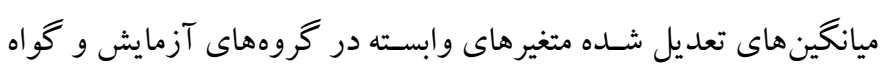

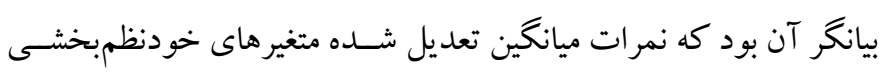

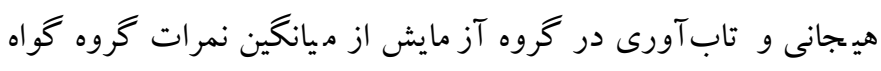

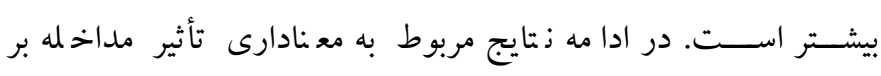
خردهمقياس هاى متغير خودنظمبخشـى هي جانى (ابراز كرى هي جانى و
با توجه به نتايج جدول س، آموزش متغير مستقل (مداخله ذهن آكاهى كودككمحور) توانسـته اســت به ايجاد تفاوت معنادار ميانكين نمرات متغيرهـاى وابســـهـ (خودنظمبخشـى هيجـانى و تـابـآورى كودكـان بدسـريرسـت) در مرحله يس آزمون در سـطح خطاى هـ • • منجر شـود؛ بنابر اين اين نتيجه حاصـلـل مى شــود كه با كنترل متغير هاى مداخله كر، ميانگين نمرات متغيرهاى خودنظم بخشىى هيجانى و تاب آورى كود كان بدســربرســت با آموزش مداخله ذهن آكاهى كودككمحور تغيير كرده اســـت. مقــدار تـأثير مــاخلـه ذهن آكَاهى كودككمحور بر ميزان خودنظمبخشى هيجانى و تاب آورى كود كان بدسريرست به ترتيب NY • 


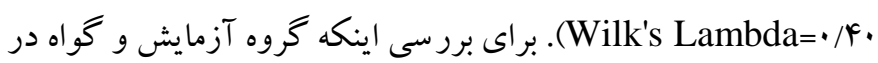

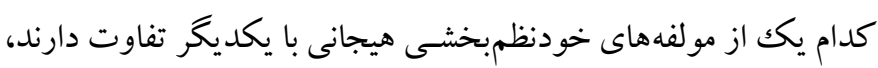

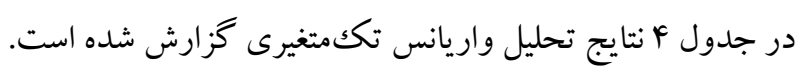

بازدارى شــناختى هيجان) به وســله تحليل كواريانس جندمتغيرى مورد

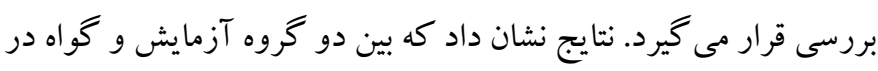

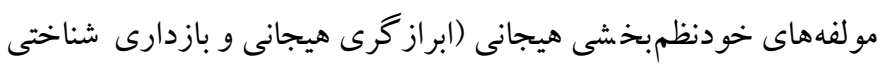

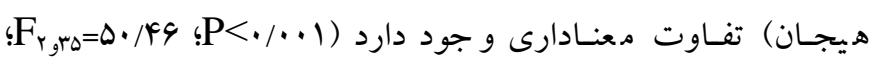

جدول ع: نتايج تحليل واريانس تكتمتيرى تفاوت كروه آزمايش و كواه در مؤلفههاى خودنظمبخشى هيجانى

\begin{tabular}{|c|c|c|c|c|c|c|c|}
\hline اندازه اثر & $\mathbf{P}$ & $\mathbf{F}$ & خطاى استاندارد & تفاوت ميانكين & ميانغين & كروه & مؤلفه \\
\hline & & & & & $19 / 1 V$ & آزمايش & \\
\hline$\cdot / F F$ & $\cdot \cdots \cdots 1$ & YN/AQ & $\cdot / V^{\prime}$ & $F / 1$. & $\mid r / \cdot V$ & كواه & ابراز گرى هيجانى \\
\hline .191 & $\cdot / \cdots 1$ & VA/VA & $\cdot / \wedge \Delta$ & $\mathrm{V} / \Delta \Lambda$ & $\begin{array}{l}r N / \Delta q \\
r I / \cdot I\end{array}$ & كَآزمايش & بازدارى شناختى هيجان \\
\hline
\end{tabular}

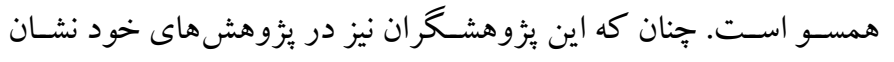

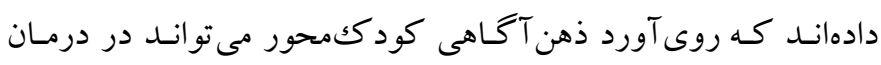

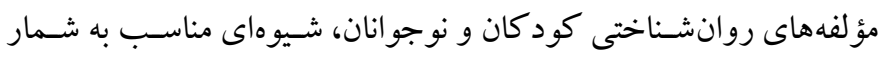

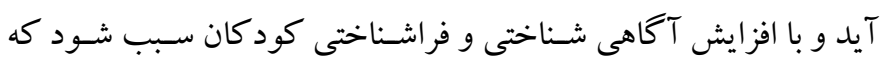

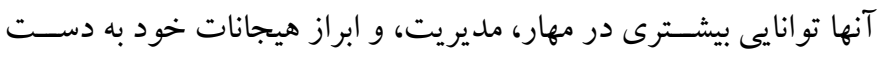

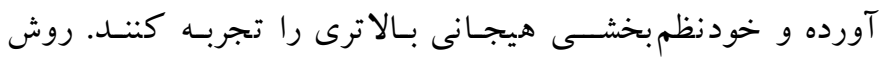

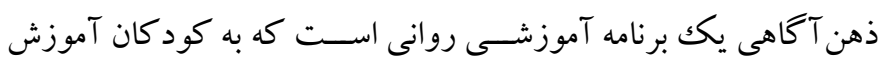

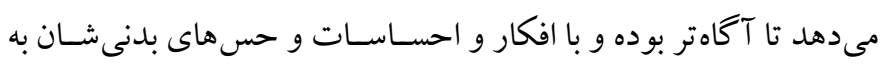

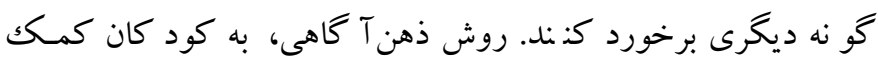

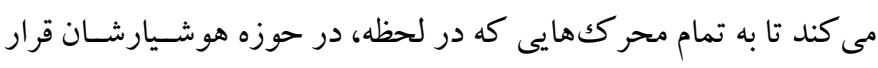

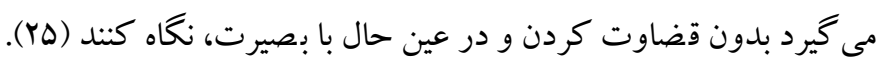

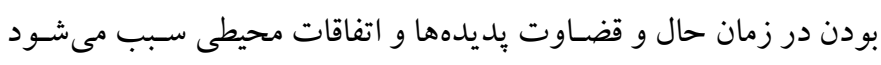

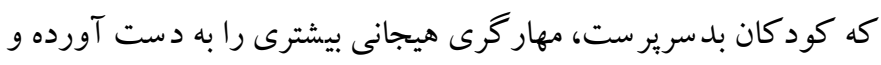

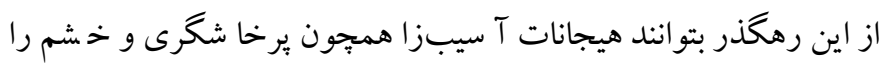

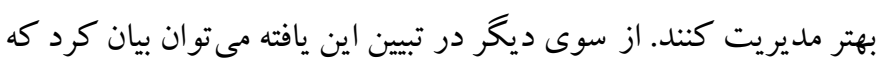
جون درمان ذهن آكاهى، مبتنى بر احســاس بدون قضــاوت و و فراتر از

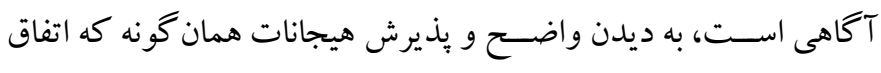

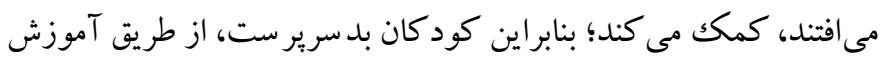

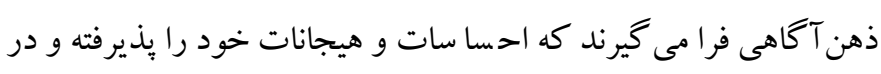

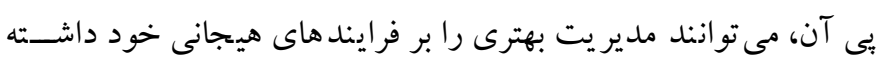

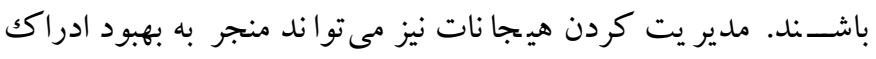

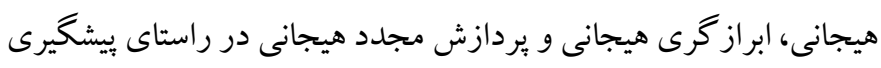

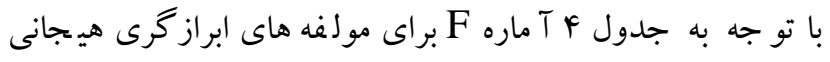

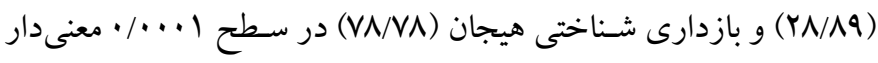

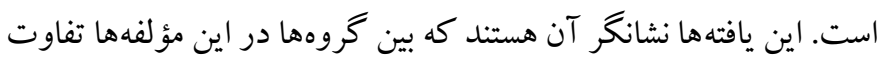

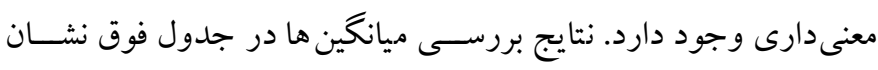

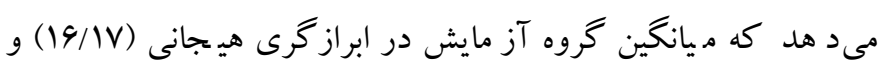

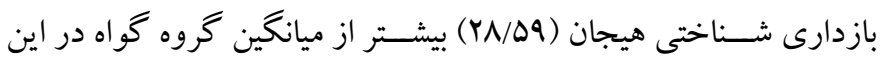

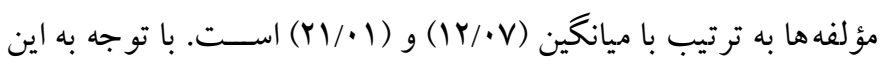

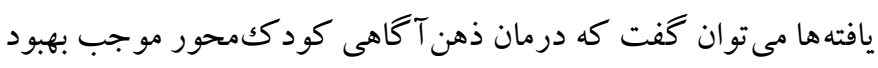

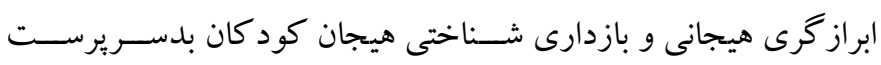

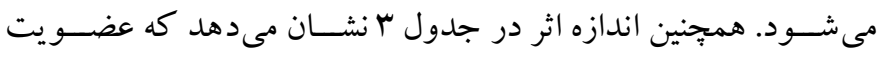

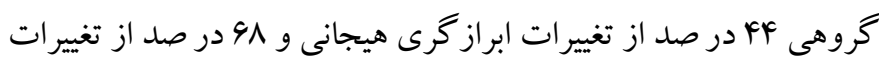
بازدارى شناختى هيجان را تبيين مى كند.

\section{بحث و نتيجه تيرى}

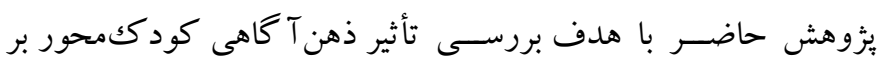

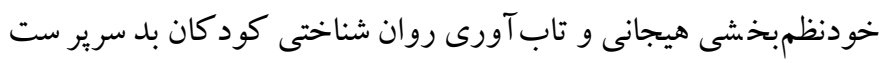

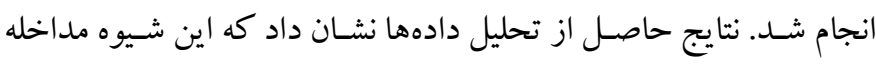
باعث بهبود خودنظمبخشى هيجانى و تاب آورى روانشسناختى كود كان

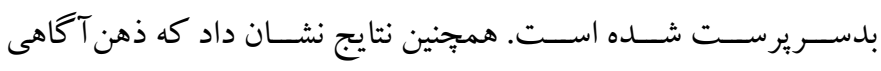
كود ككمحور بر خردهمقياس هاى نظمبخشى هيجانى (ابراز خرى هيجانى

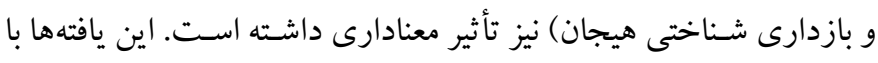

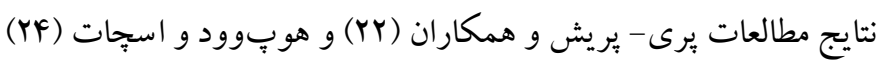


با افزايش بهزيسـتى روانشـناختى همر اه اســت. از طرفى نتايج برخى

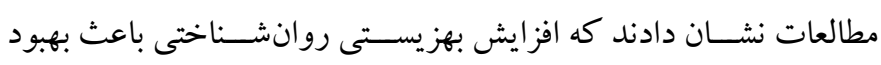

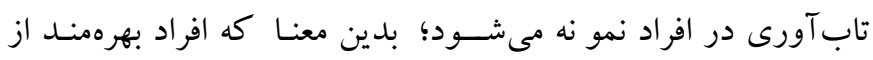

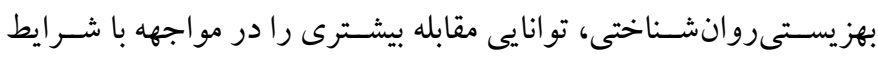

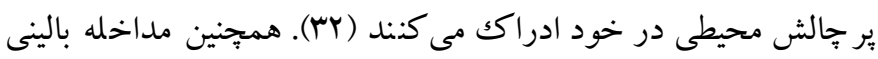

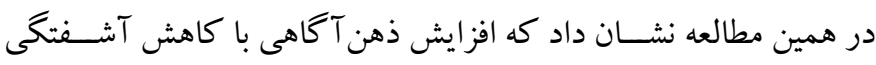

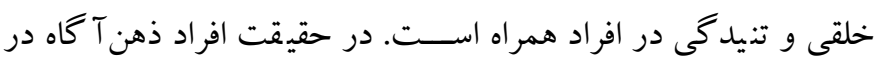

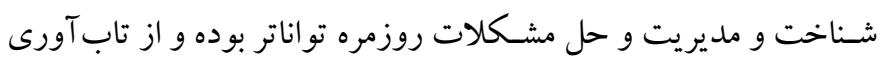

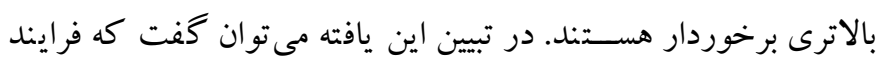
ذهن آكاهى و تمرين تمركز، موجب افز ايش ظرفيتهار هاى درونى از جمله

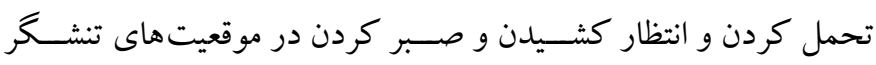

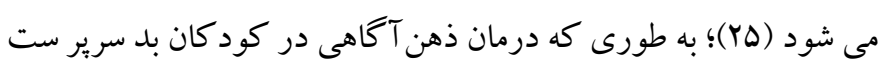

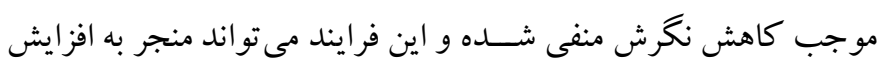

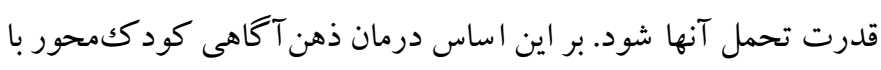

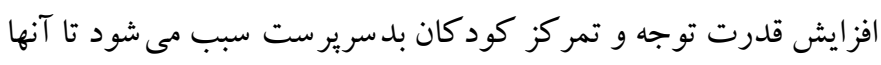

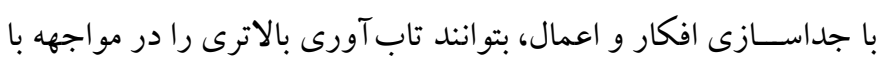

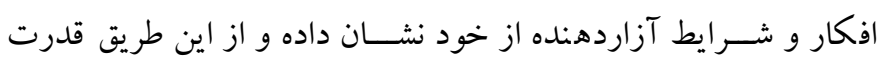

$$
\text { تاب آورى آنها نيز بهبود مى يابد. }
$$

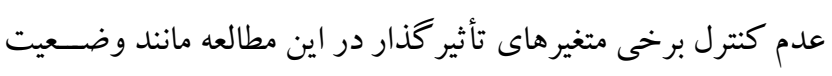

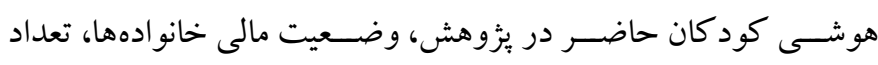

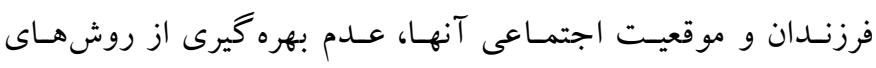

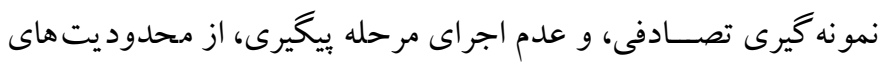

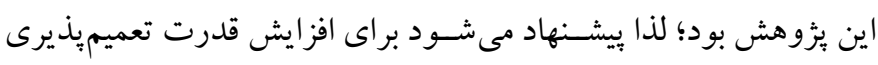

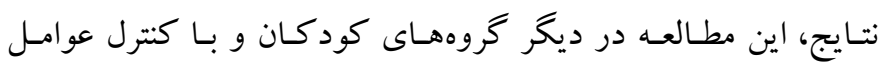

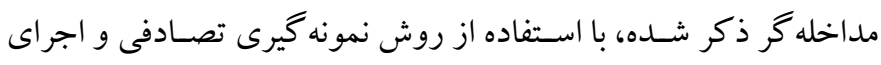

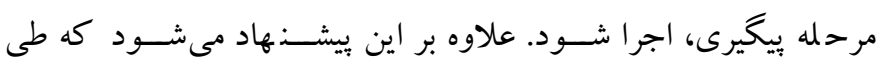

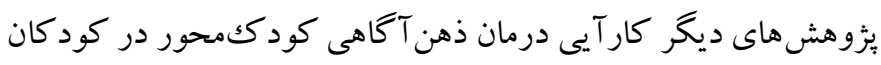

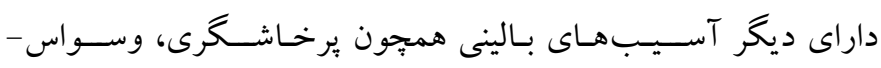

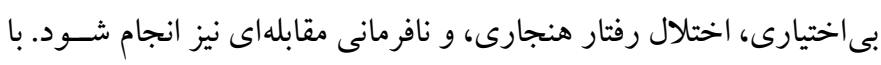

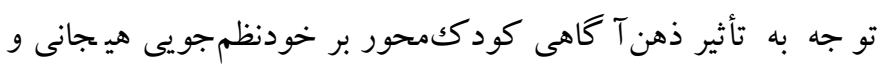

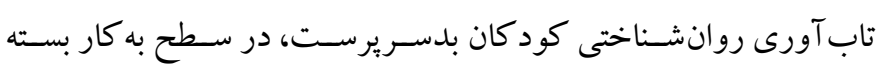

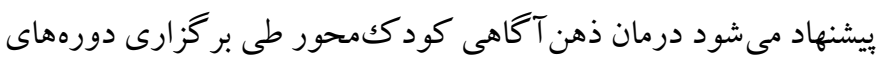

و بازدارى از ابراز هي جا نات آســيبزا منجر شــود. همجنين در مان

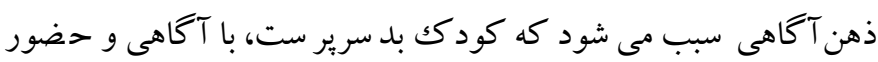

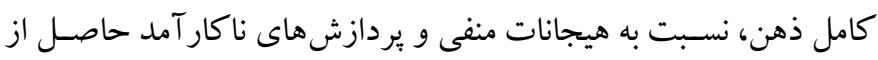

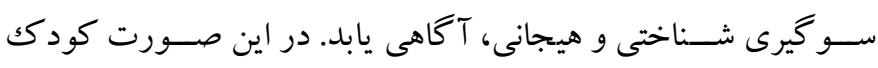

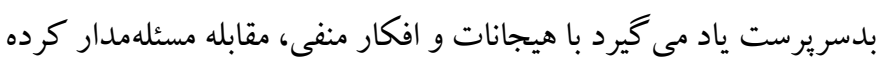

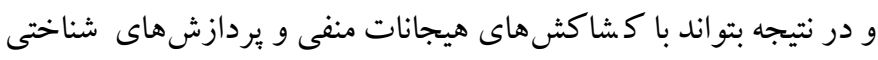

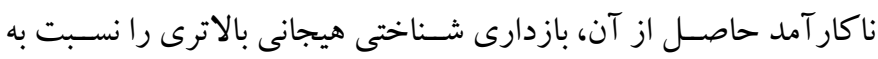

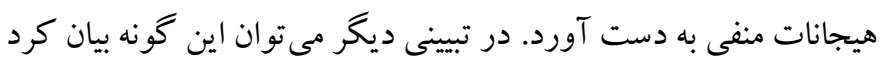

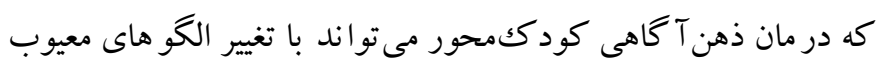

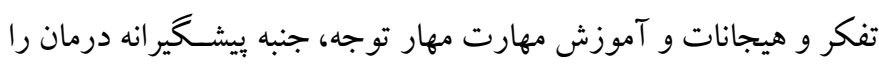

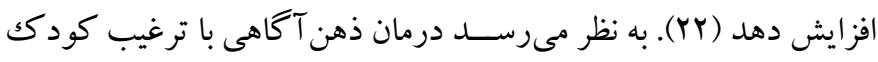

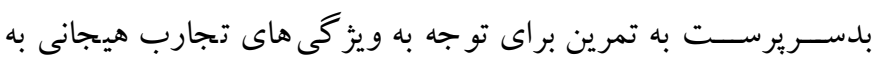

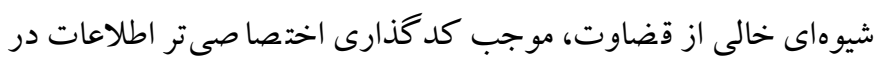

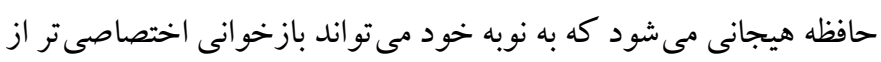
حافظه را به همر اه داشته باشد. از ديخر علل اثربخشسى ذهن آكاهى بر خودنظمبخشسى هيجانى كود كان

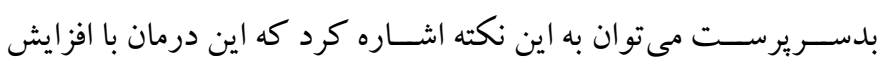

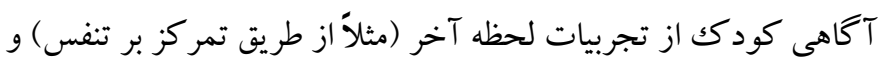

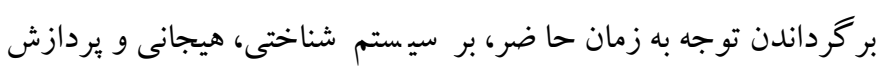

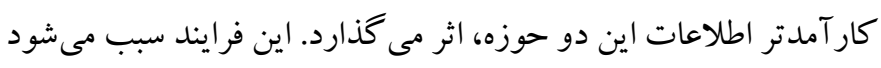

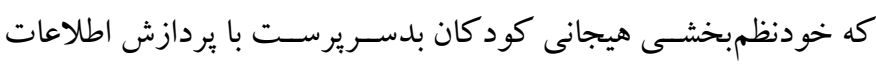

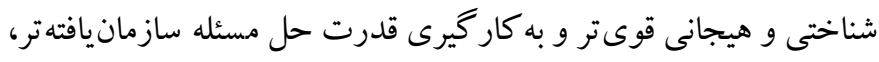

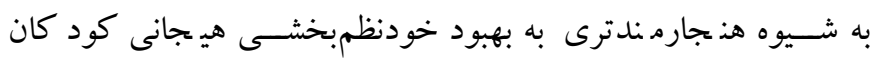

$$
\text { بلدسريرست منجر شود. }
$$

نتايج بثوهش حاضسر در باره تأثير ذهن آ كاهى كود ككمحور بر

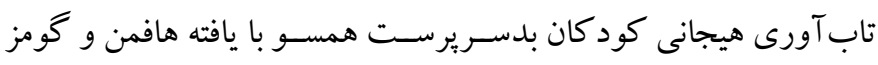

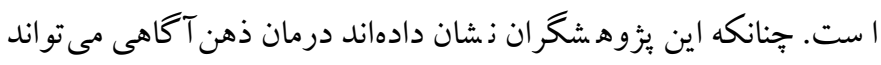

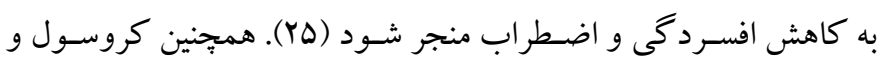

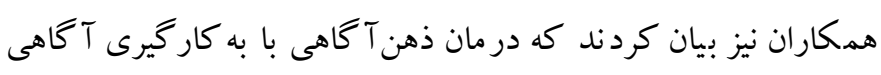

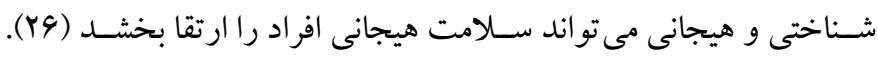

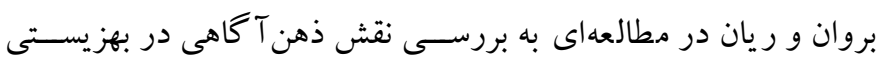

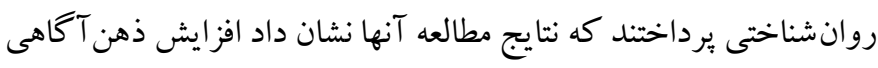




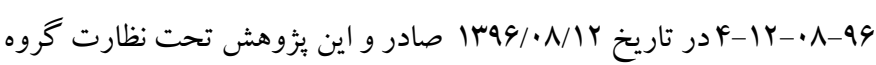

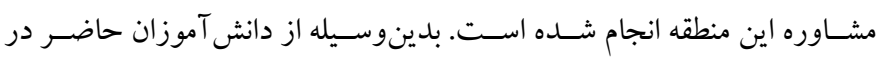

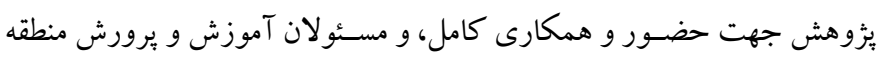
جهت صدور مجوز اجراى اين مطالعه، تقدير و تشكر شود. تضــاد منافع: در اين يثوهش هيج گونه تعارض منافعى توســ نويســند كان كز ارش نشده است.
كاملاً تخصـصـس به مشــاوران مدارس آموزش داده شـــود تا آنها با

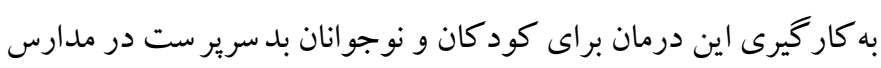

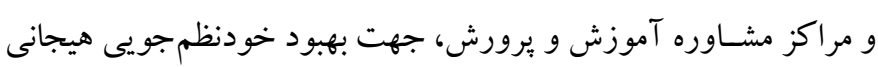
و تاب آورى روانشناختى اين كود كان و نوجوانان، اقدام كنند. تشـكر و قدردانى: اين مطالعه به صـورت مسـتقل اجرا شــده اسـت و مجوز

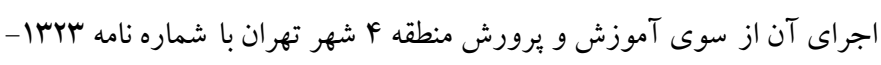




\section{References}

1. Gili S, Hashemian K, Pakdaman S, Abolmali K. Comparing the frequency of drawing characteristics of children with bad parenting and normal children aged 5-11 based on draw-a-family test. Knowledge \& Research in Applied Psychology. 2015; 16(1): 54-65. [Persian]. [Link]

2. Davies PT, Cummings EM, Winter MA. Pathways between profiles of family functioning, child security in the interparental subsystem, and child psychological problems. Dev Psychopathol. 2004; 16(3): 525-550. [Link]

3. Völkl-Kernstock S, Karnik N, Mitterer-Asadi M, Granditsch E, Steiner H, Friedrich $M H$, et al. Responses to conflict, family loss and flight: posttraumatic stress disorder among unaccompanied refugee minors from Africa. Neuropsychiatr. 2014; 28(1): 6-11. [Link]

4. Laukkanen J, Ojansuu U, Tolvanen A, Alatupa S, Aunola K. Child's difficult temperament and mothers' parenting styles. J Child Fam Stud. 2014; 23(2): 312323. [Link]

5. Shaw DS, Winslow EB, Flanagan C. A prospective study of the effects of marital status and family relations on young children's adjustment among African American and European American families. Child Dev. 1999; 70(3): 742-755. [Link]

6. Movaghar S. Effectiveness of mindfulness-based cognitive therapy to control dysfunctional thoughts in bad parent and runaway girls. Middle Eastern Journal of Disability Studies. 2017; 7: 25. [Persian]. [Link]

7. Okorodudu GN. Influence of parenting styles on adolescent delinquency in delta central senatorial district. Edo Journal of Counselling. 2010; 3(1): 5886. [Link]

8. Finlon KJ, Izard CE, Seidenfeld A, Johnson SR, Cavadel EW, Krauthamer Ewing ES, et al. Emotionbased preventive intervention: Effectively promoting emotion knowledge and adaptive behavior among atrisk preschoolers. Dev Psychopathol. 2015; 27(4): 1353-1365. [Link]

9. Hesarsorkhi R, Asghari Nekah SM, Lalzdeh Kandekali E, Parvaneh E. Comparison of aggression and emotional knowledge in orphans and abandoned male children with non- orphans male children. Quarterly Journal of Child Mental Health. 2016; 3(2): 77-85. [Persian]. [Link]

10. Malesza M. Stress and delay discounting: The mediating role of difficulties in emotion regulation. Pers Individ Dif. 2019; 144: 56-60. [Link]
11. Andrei F, Nuccitelli C, Mancini G, Reggiani GM, Trombini E. Emotional intelligence, emotion regulation and affectivity in adults seeking treatment for obesity. Psychiatry Res. 2018; 269: 191-198. [Link]

12. Benfer N, Bardeen JR, Clauss K. Experimental manipulation of emotion regulation self-efficacy: Effects on emotion regulation ability, perceived effort in the service of regulation, and affective reactivity. $\mathrm{J}$ Contextual Behav Sci. 2018; 10: 108-114. [Link]

13. Godfrey KM, Juarascio A, Manasse S, Minassian A, Risbrough V, Afari N. Heart rate variability and emotion regulation among individuals with obesity and loss of control eating. Physiol Behav. 2019; 199: 73-78. [Link]

14. Garnefski N, Teerds J, Kraaij V, Legerstee J, van den Kommer T. Cognitive emotion regulation strategies and depressive symptoms: differences between males and females. Pers Individ Dif. 2004; 36(2): 267-276. [Link]

15. Hasani J. The reliability and validity of the short form of the cognitive emotion regulation questionnaire. Journal of Research in Behavioural Sciences. 2011; 9(4): 229-240. [Persian]. [Link]

16. Honarmand Zadeh R, Sajjadian I. Effectiveness of positive group intervention on psychological wellbeing, resiliency and happiness of foster care adolescent girls. Positive Psychology. 2016; 2(2): 3550. [Persian]. [Link]

17. Veinberg I. Emotional awareness - the key to dealing appropriately with children of divorced families in schools. Procedia Soc Behav Sci. 2015; 209: 514-518. [Link]

18. Momeni K, Jalili Z, Mohseni R, Karami J, Saeedi M, Ahmadi SM, et al. Efficacy of teaching resiliency on symptoms reduction on anxiety of adolescence with heart disease. Journal of Clinical Research in Paramedical Sciences. 2015; 4(2): e81970. [Persian]. [Link]

19. Tofighi Z, Aghaei A, Gol Parvar M. Comparing effectiveness of resilience and emotion regulation on perceived social stigma and mental endurance in the mothers of the children with cerebral paralysis (CP). Psychology of Exceptional Individuals. 2018; 7(28): 71-93. [Persian]. [Link]

20. Alborzi M, Khoshbakht F, Golzar HR, Sabri M. The relationship between attachment styles and resiliency: the mediating role of emotional intelligence. Journal of Developmental Psychology Iranian Psychologists. 2015; 11(44): 425-436. [Persian]. [Link] 
21. Bordick D. Mindfulness skills for the children and adolescents. Monsheie GR, Asli Azad M, Hoseini L, Tayebi P. (Persian translator). First edition. Isfahan: Isfahan Islamic Azad University publication (Khorasgan); 2017, pp: 369-375. [Persian].

22. Perry-Parrish C, Copeland-Linder N, Webb L, Sibinga EMS. Mindfulness-based approaches for children and youth. Curr Probl Pediatr Adolesc Health Care. 2016; 46(6): 172-178. [Link]

23. Ghasemi Bistagani M, Musavi Najafi F. Effectiveness of child-centered mindfulness on social skills and selfefficacy of children with learning disabilities. Social Behavior Research \& Health. 2017; 1(2): 91-99. [Link]

24. Hopwood TL, Schutte NS. A meta-analytic investigation of the impact of mindfulness-based interventions on post traumatic stress. Clin Psychol Rev. 2017; 57: 12-20. [Link]

25. Hofmann SG, Gómez AF. Mindfulness-based interventions for anxiety and depression. Psychiatr Clin North Am. 2017; 40(4): 739-749. [Link]

26. Crosswell AD, Moreno PI, Raposa EB, Motivala SJ, Stanton AL, Ganz PA, et al. Effects of mindfulness training on emotional and physiologic recovery from induced negative affect. Psychoneuroendocrinology. 2017; 86: 78-86. [Link]

27. Kroska EB, Miller ML, Roche AI, Kroska SK, O'Hara MW. Effects of traumatic experiences on obsessive-compulsive and internalizing symptoms: The role of avoidance and mindfulness. J Affect Disord. 2018; 225: 326-336. [Link]

28. Heidarian A, Zahrakar K, Mohsenzade F. The effectiveness of mindfulness training on reducing rumination and enhancing resilience in female patients with breast cancer: a randomized trial. Iranian Quarterly Journal of Breast Disease. 2016; 9(2): 5259. [Persian]. [Link]
29. Asghari F, Ghasemi Jobaneh R, Hoseini Sedigh M, Jamei M. Effectiveness of mindfulness training on emotion regulation and quality of life of addict's wife. Counseling Culture and Psycotherapy. 2016; 7(26): 115-132. [Persian]. [Link]

30. Walsh JJ, Balint MG, Smolira SJ DR, Fredericksen LK, Madsen S. Predicting individual differences in mindfulness: The role of trait anxiety, attachment anxiety and attentional control. Pers Individ Dif. 2009; 46(2): 94-99. [Link]

31. Goldin PR, Gross JJ. Effects of mindfulness-based stress reduction (mbsr) on emotion regulation in social anxiety disorder. Emotion. 2010; 10(1): 83-91. [Link]

32. Hollis-Walker L, Colosimo K. Mindfulness, selfcompassion, and happiness in non-meditators: A theoretical and empirical examination. Pers Individ Dif. 2011; 50(2): 222-227. [Link]

33. Narimani M, Abbasi M, Abolghasemi A, Ahadi B. A study comparing the effectiveness of acceptance/ commitment by emotional regulation training on adjustment in students with dyscalculia. Journal of Learning Disabilities. 2013; 2(4): 154-176. [Persian]. [Link]

34. Soleimani E, Habibi Y. The relationship between emotion regulation and resiliency with psychological well-being in students. Journal of School Psychology. 2015; 3(4): 51-72. [Persian]. [Link]

35. Mohammadi H, Mosavi V. Comparison of emotional regulation and self-control in children with and without attention deficit/hyperactivity disorder. Quarterly Journal of Child Mental Health. 2015; 2(2): 21-33. [Persian]. [Link]

36. Kazerouni Zand B, Sepehri Shamloo Z, Mirzaiyan B. The study of psychometric features for child and youth resilience measure (CYRM- 28) in Iranian society: validity and reliability. Quarterly Journal of Health Breeze. 2013; 2(3): 15-21. [Persian]. [Link] 